\title{
Heavy metal fractionation in roof run off in Ile-Ife, Nigeria
}

\author{
${ }^{1}$ J. G. Ayenimo, ${ }^{1 *}$ A. S. Adekunle, ${ }^{2}$ W. O. Makinde, ${ }^{1}$ G. O. Ogunlusi \\ ${ }^{1}$ Department of Chemistry, Obafemi Awolowo University, Ile-Ife, Nigeria \\ ${ }^{2}$ Center for Energy and Research Development, Obafemi Awolowo University, Ile-Ife, Nigeria
}

Received 23 April 2006; revised 28 May2006; accepted 5 June 2006; available online 25 June 2006

\begin{abstract}
Runoff was collected from three different roofing materials that are commonly used for roofing in IleIfe, Nigeria, between the months of June to August, 2004. The samples were collected in four geographical locations in the town. The run offs were analysed for $\mathrm{pH}$, Temp, TDS, $\mathrm{CI}^{-}, \mathrm{SO}_{4}{ }^{2-}, \mathrm{PO}_{4}{ }^{3-} \mathrm{NO}_{3}{ }^{2-}$, $\mathrm{EC}$ and some heavy metals both as regards total, dissolved and particulate fractions. Analysis of the heavy metals was done using flame Atomic Absorption Spectrophotometer. The quantity of these parameters varies with the different roofing materials. In terms of dissolved metals, Fe is the most predominant metal with mean values $0.59 \pm 0.29,0.82 \pm 0.14$, and $1.04 \pm 0.27 \mathrm{mg} / \mathrm{L}$ for asbestos, ceramic tiles and metal sheets respectively. The tendency of the roofing materials to release dissolved metals is arranged as follows: $\mathrm{Zn}, \mathrm{Cr}$ and Fe (metal sheet $>$ Ceramic $>$ asbestos); Cd and $\mathrm{Pb}$ (asbestos $>$ ceramic $>$ metal sheet). In terms of particulate metals, the concentration of $\mathrm{Cd}$ and $\mathrm{Pb}$ are higher in the asbestos than other roofing stuffs. The sequence of their predominance in asbestos is as follows: $\mathrm{Pb}(0.83 \pm 0.55 \mathrm{mg} / \mathrm{L})>\mathrm{Cd}(0.29 \pm 0.07 \mathrm{mg} / \mathrm{L})$. In all the roofs, both particulate and dissolved metals except Zn exceeded WHO permissible limits for drinking water. The high levels of the metals obtained in this study may likely result in consumer complaints since some of the metals are not only carcinogenic but are also liable of impacting bad taste in water.
\end{abstract}

Key words: Runoff, heavy metals, roofing, flame atomic absorption spectrophotometry

\section{INTRODUCTION}

In the last decades growing urbanization has made urban runoff a major problem both from the point of view of the flow quantities and from their qualities. Numerous studies have exposed the pollution from storm waters from both separate and combined sewers (Saget, 1994) and their impact on natural waters. Traditional drainage systems, particularly in Nigeria appear inadequate and costly to manage wet weather flows and it becomes necessary to influence at all levels of the urban cycle so as to reduce the runoff volume and its pollution. Development of alternative technologies and control of wet weather pollution requires accurate data on the quantity and on the characteristics of runoff pollution from different types of surfaces before it is mixed and transported in a sewer. At present, this type of data is not readily available in the world. Though some studies have examined the importance of various urban functions as sources of metals (Xanthopolous and Halin, 1993; Sartor and Boyd, 1972; Astruc et al., 1979 and Dannecker and Stechmann, 1990) but little attention was particularly

*Corresponding author, Email: sadek2k@yahoo.com

Tel.: +234806-274 4292; Fax: +234806-274 4292 paid to roof and yard runoff in the last few decades. A study by the U.S. Environmental Protection Agency (US EPA, 1990) identified sources of lead and $\mathrm{Zn}$ in an urban setting. Bannerman (1991) related increases in Zinc and lead concentrations to increase in traffic densities. Marsalek (1986) studied urban runoff in both water column samples and sediment sample and concluded that the most prominent toxic contaminants in urban runoff are trace metals. Pitt and Baron (1989) also studied important sources of dissolved metals in the urban system. According to the Authors, parking areas are important sources of dissolved nickel and lead while streets and vehicle services areas are important sources of cadmium. Similar studies on roof were carried out in Australia (Thomas and Greene, 1993), Washington (Good, 1993) and Wisconsin (Bannerman, 1994). Direct discharges of the runoff could have toxic effects on natural waters and their local infiltration may rapidly lead to soil contamination. In reality, more and more research is focusing on the effects of urban non-point sources such as parking lots, lawn care, construction sites, street runoffs and roads while few reports exists on environmental 
implications of roof run off. The reasons may not be unconnected to the insinuation that run off collected from roofs was generally considered to be a portable and environmentally safe source of water. For instance, some studies indicate that roof runoffs are generally significantly cleaner than other storm water sources when contaminants such as sediment, nutrients, organic material and bacteria are considered. However, it appears that this does not necessarily apply to dissolve and particulate metals such as copper, lead, and especially zinc and total metals generally (Chang and Crawley, 1993 and Foster, 1996). Products used in roofs appear to have a direct influence on the potential for the release of these metals to storm water. Roofs are made of variety of materials, and most, with the exception of those made from grass/reed and potentially toxic materials, are suitable as rainwater catchments surfaces. The typical roofing materials that are commonly used in Nigeria today and particularly in Ile-Ife are ceramic tiles, metal sheets, galvanized iron, anodized aluminum and asbestos. All these materials are a potentially source of dissolved ions, alkalinity and trace metals. For instance, the safety of water harvested from asbestos (asbestos-reinforced cement mortal) roofs has been queried, but the consensus is that the danger of developing cancer from infested asbestos is very slight (Campbell, 1993). The danger from the inhaled asbestos dust is however sufficiently high that working with asbestos sheathing, for example, sawing it, without special protection is generally banned. Indeed, the British and Belgian governments outlawed the use of asbestos in Britain and Belgium. Similarly, the widespread use of asbestos in manufacturing in United States of America ended in the 1970s. In Nigeria, asbestos is manufactured in many centrally located cities like Kano, Lagos and Sapele and promoted as an essential ingredient for building. Therefore, this present study attempts to serve as an eye-opener to the rapidly growing environmental threats posed by some commonly used roofing materials for rain harvesting in Nigeria.

\section{MATERIALS AND METHODS}

Rainwater was harvested between June and August 2004 from the different roofs in four densely populated areas of Ile-Ife Nigeria. The samples were collected after several rainfalls to minimize pollution due to atmospheric sources from 8 rain events that always lasted for about 2 h. Two to four days dry weather periods were observed between each rain events. Samples were also collected directly from the sky to serve as a control. The samples were collected in $1 \mathrm{~L}$ acid leached polythene containers for the determination of total metal concentration and also particulate and dissolved fractions of five selected metals. The $\mathrm{pH}$, Temp, EC, and TDS were determined immediately in the sample. The analytical scheme proposed by Hart and Davies, (Hart and Davies, 1981) was adopted and modified to partition metals into two different operationally defined fractions of dissolved and particulate metals. About $500 \mathrm{~mL}$ of the runoff samples were filtered immediately through $0.45 \mu \mathrm{m}$ cellulose membrane filter paper for the speciation analysis, while the remaining $500 \mathrm{~mL}$ water sample were used for total metal analysis. All the samples were acidified with high purity $6 \mathrm{M} \mathrm{HNO}_{3}$ and refrigerated pending analysis. The filtrate obtained was analyzed for dissolved metals, while the particulate matter retained on the $0.45 \mu \mathrm{m}$ filter paper was digested with $20 \mathrm{~mL}$ of Conc. $\mathrm{HNO}_{3}$ at about $100^{\circ} \mathrm{C}$ for $6 \mathrm{~h}$ to almost dryness in a Teflon beaker. The metals were recovered with $20 \mathrm{mls}$ of $1 \% \mathrm{HNO}_{3}$ centrifuged and decanted. The supernatant liquid was analyzed for particulate metals. The samples for total metal determination were digested in similar way to particulate matter. The blank was taken on the reagents through the complete procedure except that the sample was omitted. Triplicate determinations were made on the samples. The concentrations (mg/L) of five metals $\mathrm{Zn}, \mathrm{Pb}, \mathrm{Fe}$, $\mathrm{Cd}$ and $\mathrm{Cr}$ were determined in the samples and the blanks with a computerized Buck Scientific model 200a/ 210 flame atomic absorption spectrophotometer (Milner and Peterside, 1984). The instrument working condition and parameters for the determinations are shown in Table 1. Standard solution of the respective metals was used for calibration. All chemicals were analytical reagents grade obtained from British Drug.

\section{RESULTS}

The physiochemical parameters of the roof runoff are presented in Table 2. The results of Temperature and $\mathrm{pH}$ did not follow any strict pattern. Values obtained in this study were also compared with the World Health Organization Standard. The mean level of heavy metals in roof run-off samples collected from three different roof materials in Ile-Ife, Nigeria is presented in Table 3. In this result, levels of total, dissolved and particulate metals are discussed. Data obtained for dissolved metals in this study were compared with those of previous workers as presented in Table 4. 
Heavy metal fractionation...

Table 1: Working conditions of buck scientific spectrometer for the determination of metals

\begin{tabular}{cccccc}
\hline Metals & $\begin{array}{c}\text { Wave length } \\
(\mathrm{nm})\end{array}$ & $\begin{array}{c}\text { Slit width } \\
(\mathrm{nm})\end{array}$ & $\begin{array}{c}\text { Lamp current } \\
(\mathrm{mA})\end{array}$ & $\begin{array}{c}\text { Characteristics } \\
\text { concentration } \\
(\mathrm{mg} / \mathrm{L})\end{array}$ & $\begin{array}{c}\text { Detection limit } \\
(\mathrm{mg} / \mathrm{L})\end{array}$ \\
\hline $\mathrm{Fe}$ & 248 & 2 & 6.5 & 0.060 & 0.020 \\
$\mathrm{Zn}$ & 214 & 2 & 4 & 0.009 & 0.006 \\
$\mathrm{~Pb}$ & 283 & 7 & 7.5 & 0.100 & 0.080 \\
$\mathrm{Cd}$ & 228 & 7 & 5.5 & 0.010 & 0.010 \\
$\mathrm{Cr}$ & 357 & 7 & 6.5 & 0.059 & 0.005 \\
\hline
\end{tabular}

Table 2: Physico-chemical parameters of roof run off

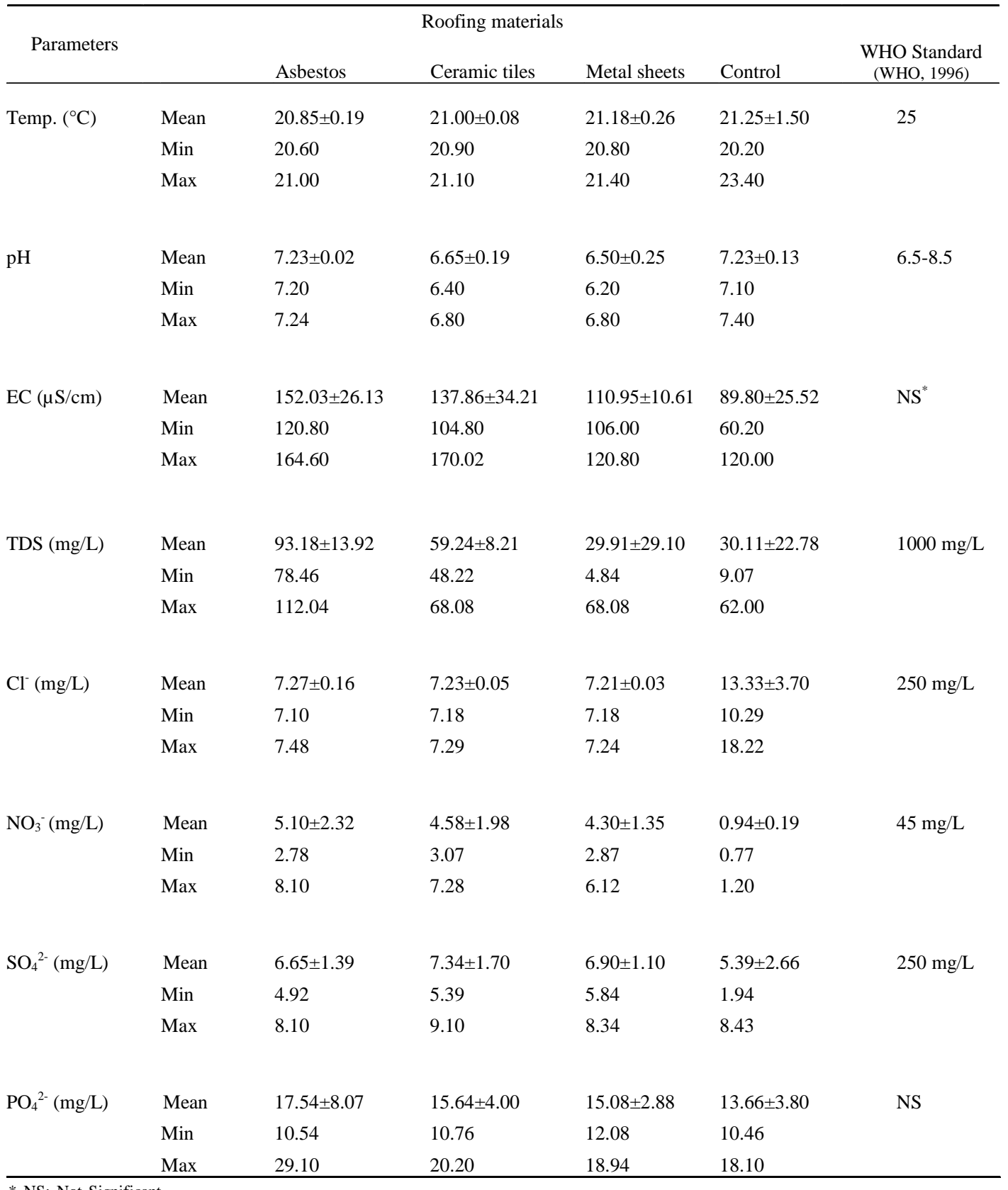

* NS: Not Significant 
J. G. Ayenimo, et al.

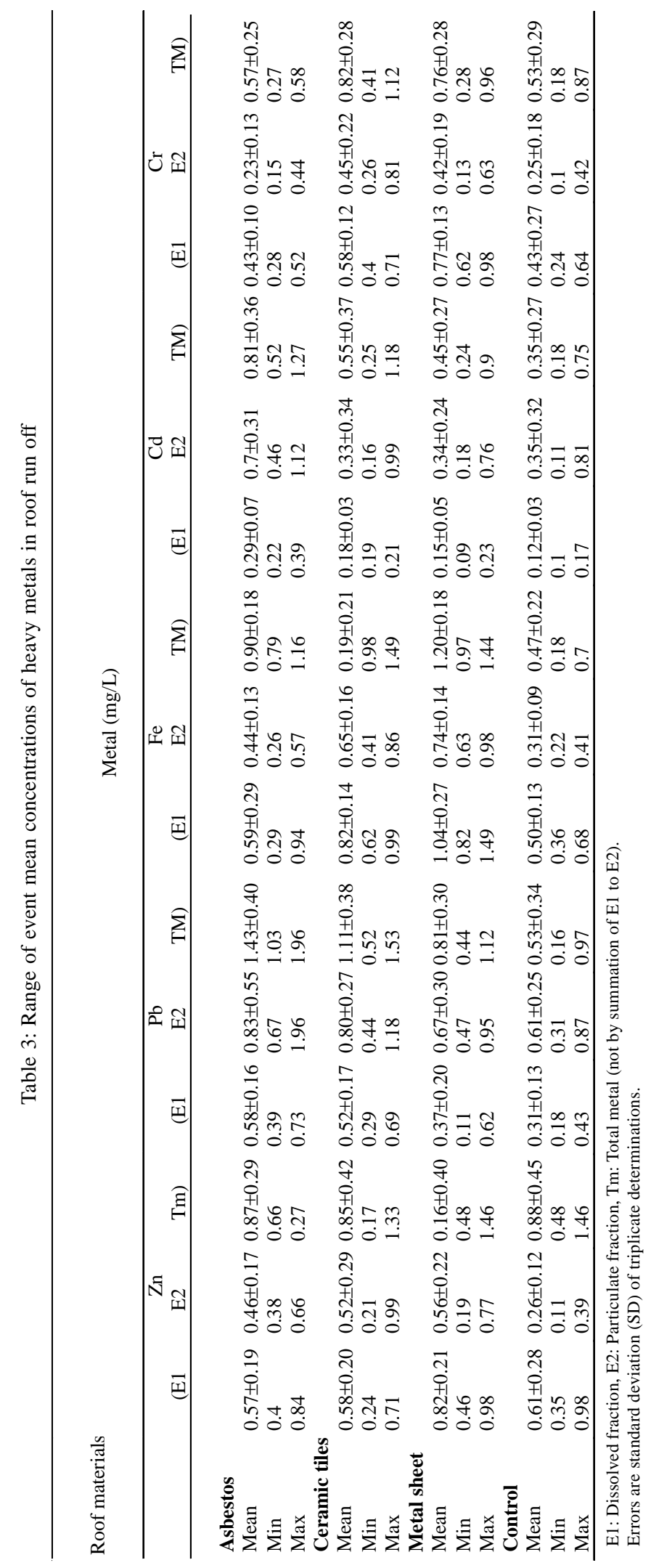


Heavy metal fractionation...

Table 4: Range of dissolved metal concentrations from urban runoffs

\begin{tabular}{|c|c|c|c|c|c|c|c|c|}
\hline \multirow[t]{2}{*}{$\begin{array}{l}\text { Metals } \\
(\mathrm{mg} / \mathrm{L})\end{array}$} & \multirow[b]{2}{*}{ *Roofs } & \multicolumn{2}{|l|}{ Gromaire, et al. } & \multicolumn{4}{|c|}{ Urban sources } & \multirow[b]{2}{*}{$\begin{array}{c}\text { Landscape } \\
\text { area }\end{array}$} \\
\hline & & Roofs & Roofs & Parking & Storage & Streets & $\begin{array}{l}\text { Vehicle } \\
\text { service }\end{array}$ & \\
\hline $\mathrm{Zn}$ & $0.21-0.98$ & $0.80-38.06$ & $0.10-1.58$ & $0.03-0.15$ & $0.07-0.29$ & $0.06-013$ & $0.07-0.13$ & $0.03-1.16$ \\
\hline $\mathrm{Pb}$ & $0.11-0.78$ & $0.02-2.76$ & $0.01-0.17$ & $0.03-0.13$ & $0.03-0.33$ & $0.03-0.15$ & $0.08-0.11$ & $0.009-0.07$ \\
\hline $\mathrm{Fe}$ & $0.29-1.49$ & ND & ND & ND & ND & $\mathrm{ND}$ & ND & ND \\
\hline $\mathrm{Cd}$ & 0.09-0.39 & 0.0001-0.03 & $0.0008-0.03$ & $0.007-0.07$ & $0.002-0.01$ & $0.0007-0.22$ & $\begin{array}{l}0.0008- \\
0.003\end{array}$ & $\begin{array}{l}0.00004- \\
0.001\end{array}$ \\
\hline $\mathrm{Cr}$ & $0.28-0.09$ & ND & ND & ND & ND & ND & ND & ND \\
\hline $\mathrm{Ni}$ & ND & ND & $0.005-0.07$ & $0.04-0.13$ & 0.03-0.09 & $0.003-0.07$ & $0.04-0.07$ & $0.03-013$ \\
\hline
\end{tabular}

*Present study; ND: Not determined

\section{DISCUSSION AND CONCLUSION}

The result of the analysis of the blank solution indicates no contamination from the reagents used as all the metals were below their detection limits. According to Table 2, the samples appear to be relatively acidic with the $\mathrm{pH}$ values ranging from 6.207.24. More so, this study indicates that other water parameters like TDS, $\mathrm{CI}^{-}, \mathrm{SO}_{4}{ }^{2-}, \mathrm{PO}_{4}{ }^{3-}, \mathrm{NO}_{3}{ }^{2-}$ and $\mathrm{EC}$ are appreciably higher in the roof runoff than the control samples. The droplets from birds, fallen of leaves, particulate matters and other assorted materials present on the roof may be responsible for these higher values. In all the roof investigated, a metal sheet has the least values of the parameters. This may be due to its smooth surface and high heat capacity, which allow the debris and particulate matter on it to dry within a very short time and fall off by wind or rain unlike the asbestos, which are most likely to retain contaminants. All the values obtained in this study for water parameters may impact bad taste to water and likely result in consumer complaints. However, this may not necessarily be toxic since all the values fall within acceptable range of World Health Organization (WHO, 1996) guidelines for water quality of rain water systems. Although, no limits are defined for conductivity but the values should not reflect an associated total dissolved solids (TDS) level higher than the limit since the TDS levels are within the limits, the conductivity values recorded for the rainwater from different roofing materials $(89.80 \pm 25.52$ $\mu \mathrm{S} / \mathrm{cm}-152.03 \pm 26.13 \mu \mathrm{S} / \mathrm{cm})$ are similarly acceptable values. In Table 3, most of the metals have their concentrations higher in all the roofs investigated than in the control, thus indicating contributions of roof materials to heavy metals load of rainwater. In terms of dissolved metals, this study suggests that metal sheet contribute more Fe $(1.04 \pm 0.27 \mathrm{mg} / \mathrm{L}), \mathrm{Zn}(0.82 \pm 0.21$ $\mathrm{mg} / \mathrm{L})$ and also more $\mathrm{Cr}(0.77 \pm 0.13 \mathrm{mg} / \mathrm{L})$ to roof run off than other roofs investigated. While Asbestos has the highest values of $\mathrm{Pb}(0.58 \pm 0.16 \mathrm{mg} / \mathrm{L})$ followed by Cd $(0.29 \pm 0.07 \mathrm{mg} / \mathrm{L})$. The values of dissolved metals under this study were observed to be far below those of previous works (Pitt and Barron, 1989 and Gromaire mertz et al., 1999) as shown in Table 4. These lower values may be attributed to the fact that there is virtually no industries in the studied area unlike the highly industrialized areas where the previous works were conducted. The unexpectedly high values of cadmium in this present study compare with the previous works may be attributed to the variance in the types of roof investigated. As observed under this present study, the roofs can be arranged in this predominant order of desorbing dissolved metals: $\mathrm{Zn}, \mathrm{Cr}$ and Fe (metal sheet $>$ ceramic $>$ asbestos) while that of $\mathrm{Cd}$ and $\mathrm{Pb}$ is (asbestos $>$ ceramic $>$ metal sheet). The maximum load (mg/L) of dissolved $\mathrm{Zn}, \mathrm{Cr}$ and Fe in the metal sheet suggests that metal roofs either galvanized iron or anodized aluminum act as a more potential source of those soluble fraction of metals than other roof types. Similarly, maximum levels of $\mathrm{Cd}$ and $\mathrm{Pb}$ were observed in asbestos than other roofing materials. This observation agrees with the reports of Gadd and Kennedy, (Gadd and Kennedy, 2001) who suggested that galvanized metal roofs contribute more zinc in roof run-off. This report implies that products used in roofs appear to have direct influence on the potential for the release of these soluble metals to storm water. The very high concentration of dissolved metal measured in the roof runoff can make its infiltration hazardous. It can lead locally to soil contamination, and in the case where groundwater level is near to the ground level it may represent a threat for the quality of ground water. In terms of particulate metals, the concentration of $\mathrm{Cd}$ and $\mathrm{Pb}$ are higher in the asbestos than other roofing 
stuffs. The sequence of their predominance in asbestos is as follows: $\mathrm{Pb}(0.83 \pm 0.55 \mathrm{mg} / \mathrm{L})>\mathrm{Cd}(0.29 \pm 0.07 \mathrm{mg} /$ $\mathrm{L})$. Similar trend was observed for dissolved $\mathrm{Pb}$ and $\mathrm{Cd}$. Specifically, the order in which the roofs are liable of releasing particulate metals into the receiving sewer are: Pband Cd (asbestos $>$ ceramic $>$ metal sheet), Cr (ceramic $>$ metal sheet $>$ asbestos), and $\mathrm{Zn}$ and Fe (metal sheet $>$ ceramic tiles $>$ asbestos). For all the metal studied, the concentration of particulate $\mathrm{Pb}$ and $\mathrm{Cd}$ were higher than the dissolved fractions in all the roofs. This could be attributed to the fact that lead is strongly bound to particles (Astruc et al., 1979 and Dannecker and Stechmann, 1990). This may also apply to Cd because lead and cadmium are associative (Alloway and Ayres, 1997). These results join the observation made by Forster, (Foster, 1996) for the roof runoff. For street runoff, most authors agree that lead is strongly associated with particles (Astruc et al., 1979 and Dannecker and Stechmann, 1990) but the results differ for $\mathrm{Cu}$ and $\mathrm{Zn}$. Most $\mathrm{Pb}$ compounds are generally insoluble in water and this may be responsible for their great affinity for particulate matter. Except for hydrocarbon and lead, which are mainlybound to particle for almost all samples, the distribution between dissolved and particle bound pollution is very fluctuant. However, solids are the main vector pollution in street and yard runoff, whereas the part of dissolved pollutions is far more important for roof runoff. (Gromaire-mertz et al., 1999). In all the roofs, both particulate and dissolved metals exceed their allowable limits except for $\mathrm{Zn}$, which is ever known to be less toxic to humans. These high levels of the metals may impact bad taste to water and may also cause ill health. The WHO guidelines values of the metals are $\mathrm{Cd}(0.003 \mathrm{mg} / \mathrm{L}), \mathrm{Fe}(0.3 \mathrm{mg} / \mathrm{L}), \mathrm{Pb},(0.01$ $\mathrm{mg} / \mathrm{L})$, Zinc (3.0 mg/L) (WHO, 1996). Based on the present study, it appears that the type of roofs used in building does influence runoff quality. In particular, there is a clear indication that roofs made of metal elevate the concentration of that metal in the runoff. It was also observed that asbestos posses more environmental risk than other roofs investigated and hence, should not be used as roofing materials not to talk of using it for rain harvesting. Up to the very high metal concentration measured on roof runoff sample, their direct discharges could have toxic effects on natural waters and their local infiltration would rapidly lead to soil contamination. Alternative technologies, especially infiltration and water re-use, should be implemented with caution. A preliminary treatment of runoff is necessary.
Nevertheless, setting alone is not sufficient due to relatively high level of dissolved pollution. Thus, novel methods, involving adsorption processes, ion exchange or flocculation, have to be developed for a fast and affording runoff pretreatment. The issue of the treatment and disposal of the removed solids and pollutants should also be developed. Lead materials are still in use at roofing joints and this may result in hazardous levels of lead in water collected. Therefore lead fitting are not recommended. The collection of water from metallic roofs when acidic rain is present should be cautioned as more corrosion and leaching of metals from roofs will occur under these conditions. Since metal roof not only get hot in the tropical region, especially in Nigeria, to sterilize themselves, but are also comparatively smooth and less likely to retain contamination (eg. dust, leaves, birddroppings) than rougher ceramic tile roofs, hence, they are recommended to be used in preference to other roof materials. The use of asbestos for roofing in Nigeria should be completely discouraged. Given the results of this present study, Nigerian government should establish an 'Agency' for Quality control Assurance that would ensure that the roofing materials comply with International Standard or American Standard of Testing Materials (ASTM). More importantly, there must be a community education to enlighten people about the dangers associated with the use of some roof materials. This would definitely encourage them to support any proposed restrictions on some types of roofing stuff in Nigeria. And to support any purposed restrictions for roofing materials in Nigeria, the Agency would carry out a review of various roofing materials for residential and industrial situations. The review would generate a list of roofing alternative and the associated costs.

\section{REFERENCES}

Alloway, B. J. and Ayres, D. C., (1997). Chemical principles of

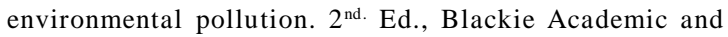
Professional, 196

Astruc, A., Astruc, M., Belgium, S. and Mericam, P., (1979). Qualite chimique des aux de ruisselement d'une vile moyenne. T.S.M. L'EAU, 74 (2), 79-85.

Bannerman, R. (1994). Sources of urban storm water pollutants defined in Wisconsin. Tech. Note 15. Water Protect. Techniq., 1 (1), 30-31.

Bannerman, R., (1991). Pollutants in Wisconsin storm water, unpublished report by the Wisconsin Department of Natural Resources, Madison, W.

Campbell, D., (1993). Asbestos roofing and safety. Raindrop, 7-12.

Chang, M. and Crawley, C. M., (1993). Preliminary observations on water quality of storm runoff from four 
selected residential roofs. Wat. Res. Bull., 29 (5), 777-783.

Dannecker, W., Au, M. and Stechmann, H., (1990). Substance load in rainwater runoff from different streets in Harmburg. Sci. Tot. Envron., 93, 385-392.

Environmental Protection Agency, (1990). National water quality inventory-1988 Report to Congress. U.S. EPA, EPA 440-4-90-003, Office of Water, Washington, D.C.

Foster, J. (1996). Patterns of roof runoff contamination and their potential implications in practice and regulation of treatment and local infiltration. Wat. Sci. Tech., 33 (6), 39-48.

Gadd, J. and Kennedy, P. (2001). House runoff: is it as clean as we think? Second South Pacific Stormwater Conference.

Good, J. C., (1993). Roof runoff as a diffuse source of metals and aquatic toxicity in storm water. Wat. Sci. Tech., 28 (35), 317-322.

Gromaire-Mertz, M. C. Garnaud, S. Gonzalex and A. Chebbo, G., (1999). Characterization of urban run off pollution in Paris. Wat. Sci. Tech., 39 (2), 1-8.

Hart, B. T. and Davies, S. H. R, (1981). Trace metal speciation in three Victorian lakes. Aust. J. Marine Freshwater Res., 32, 175-189.

Marsalek, J., (1986). Toxic contaminants in urban runoff. In: Urban runoff pollution. Torno, H., Marsalek, J., and Desbordes, M., Eds., Springer Verlag, Berlin., 39-57.
Milner, B. and Peterside J. W., (1984). Introduction to atomic absorption spectrometry scientific and equipment, $3^{\text {rd. }}$ Ed., 13.

Pitt, R. and Barron, P., (1989). Assessment of urban and industrial storm water runoff toxicity and the evaluation/ development of treatment for runoff toxicity abasement Phase 1. A report for the U.S. Environmental Protection Agency, Storm and Combined Sewer Pollution Program, Edison, NJ.

Saget, A. (1994). Base de donnees sur la qualite des rejects urbans de temps de pluie; distribution de la pollution rejetee, dimension des outrages d'interception. Ph.D. Thesis, Ecole Nationale des ponts et Chaussees, Paris, France, 333.

Sartor, J. P. and Boyd, G. B., (1972). Water pollution aspects of streets surface contaminants. In: EPA- R2 - 72- 081, U.S Environmental Protection Agency.

Thomas, P. R. and Greene, G. R., (1993). Rain water quality from different roof catchments. Water science and technology. 28 (3-5), 291-297.

WHO, (1996). Guidelines for drinking water quality, $2^{\text {nd. }}$ Ed., World Health Organization, Geneva, 2.

Xanthopolous, C. and Halin, H. H., (1993). Anthropogenic wash off from street surfaces, In: proceedings of the $5^{\text {th. }}$ International Conference on Urban Storm Drainage, Niagora Falls, Ontario, Canada. Marsalek, J. and Torno, H. C. Eds. Seapoint Publishing British Columbia. 417-422.

\section{AUTHOR(S) BIOSKETCHES}

Ayenimo, J. G., M.Sc., lecturer, Department of Chemistry, Obafemi Awolowo University, Ile-Ife, Nigeria.Email: ayenimo71@yahoo.com

Adekunle, A. S., M.Sc., lecturer, Department of Chemistry, Obafemi Awolowo University, Ile-Ife, Nigeria.Email: sadek2k@yahoo.com

Makinde,W. O., B.Tech., M.Sc., researcher, Center for Energy Research and Development ObafemiAwolowo University, Ile-Ife,Nigeria. Email: dotmark4great@yahoo.co.uk

Ogunlusi., G. O., M.Sc., lecturer, Obafemi Awolowo University, Ile-Ife, Nigeria.

Email:rogunlusi@yahoo.com

This article should be referenced as follows:

Ayenimo, J. G., Adekunle, A. S., Makinde,W. O. and Ogunlusi., G. O., (2006). Heavy metal fractionation in roof run off in Ile-Ife, Nigeria. Int. J. Environ. Sci. Tech., 3 (3), 221-227. 